\author{
Kornelia KWIECIŃSKA ${ }^{1}$ \\ Jerzy ZWOŹDZIAK ${ }^{2}$
}

January - March

\title{
ZIELONE DACHY JAKO TECHNOLOGIA WZORCOWA DLA IDEI ROZWOJU ZRÓWNOWAŻONEGO
}

\begin{abstract}
Idea rozwoju zrównoważonego wyznacza nowe priorytety, odpowiadające światowym koncepcjom ekonomicznym, ekologicznym i społecznym i stanowi szansę na rozkwit innowacyjności. Rozwój zrównoważony opiera się na świadomym działaniu całego społeczeństwa na rzecz ochrony środowiska naturalnego i zapewnienia przyszłym pokoleniom odpowiednich warunków życia, w obliczu ciągle powiększającej się liczby ludności na Ziemi. Koncepcja rozwoju zrównoważonego jest podstawowym elementem strategii rozwoju, proponowanych przez największe organizacje światowe, takie jak ONZ czy Unia Europejska. Priorytetem tych strategii są innowacyjne rozwiązania technologiczne, mające na celu dostosowanie działalności człowieka do zmieniających się warunków środowiska. Technologia ekstensywnych dachów zielonych, stosowana na obszarach silnie zurbanizowanych, przynosi bardzo wiele korzyści, zarówno dla środowiska naturalnego, jak i mieszkańców miast. Biorąc pod uwagę różnorodność pozytywnych aspektów tej technologii, jest to technologia wzorcowa dla idei rozwoju zrównoważonego. Poprzez zwiększanie świadomości społecznej $\mathrm{w}$ tym zakresie, wspieranie inicjatyw oddolnych i partycypacji społecznej w projektach środowiskowych, stwarza się szansę na upowszechnienie idei rozwoju zrównoważonego i zmianę wizerunku dzisiejszych terenów miejskich. Istotne jest również zwiększanie świadomości społecznej w zakresie konieczności dostosowywania miast do zmian klimatu, m.in. poprzez wprowadzanie zielonej infrastruktury na tereny miejskie - zielona infrastruktura zapewnia poprawę jakości powietrza, mikroklimatu miejskiego, przyczynia się do zwalczania zjawiska miejskiej wyspy ciepła, zapewnia retencję rozproszoną, wpływa na poprawę wydajności energetycznej budynków, jak również przyczynia się do wspierania bioróżnorodności.

Słowa kluczowe: rozwój zrównoważony, zielone dachy, innowacyjność, zielona infrastruktura, zmiany klimatu.
\end{abstract}

\section{WSTĘP}

Jednym z największych problemów współczesnego świata jest zanieczyszczenie środowiska, którego przyczyną jest m.in. stale powiększająca się liczba ludności na świecie. Raporty ONZ wykazują, że od roku 1950 liczba ludności świata się podwoiła, do 2050 r. ma osiągnąć ponad 9 mld. Przeludnienie jest szczególnie widoczne na obszarach stale rozrastających się aglomeracji miejskich. Głównymi czynnikami napędzającymi trend migracji do miast są m.in. podłoże ekonomiczne (większa dostępność miejsc pracy)

\footnotetext{
${ }^{1}$ Dr Kornelia Kwiecińska, Centrum Zarządzania Ryzykiem Środowiskowym i Monitoringu Ekosystemów, Uniwersytet Przyrodniczy we Wrocławiu.

${ }^{2}$ Prof. dr hab. inż. Jerzy Zwoździak, PIB IMGW Warszawa, e-mail: zwozdziak@wp.pl
} 
i socjalne (szerszy dostęp do usług publicznych i edukacji). Według ONZ, do 2050 r. aglomeracje miejskie będzie zamieszkiwało 75\% populacji ludzi. Dostarczenie energii zasilającej wciąż powiększające się miasta, jak i rozwój przemysłu, wiążą się z emisją ogromnych ilości gazów cieplarnianych i zanieczyszczeń powietrza. W wyniku zaburzenia naturalnego cyklu dwutlenku węgla $\left(\mathrm{CO}_{2}\right)$ w atmosferze, narasta zjawisko ocieplenia klimatu, mające niszczący wpływ na środowisko naturalne. Wg raportu WWF (World Wild Fund) z 2012 r., ludzie zużywają o połowę więcej zasobów Ziemi, niż planeta jest $w$ stanie odtworzyć. Oznacza to, że liczba ludności świata już dzisiaj przekracza pojemność środowiska i że rozwój cywilizacji ma charakter ekstensywny (niezrównoważony)

Główne negatywne następstwa rozrastania się miast:

- przekroczenia dopuszczalnych stężeń zanieczyszczeń powietrza i gazów cieplarnianych;

- wysokie wskaźniki zużycia energii;

- zaburzenie naturalnego obiegu wody i zjawisko miejskiej wyspy ciepła;

- problemy gospodarki odpadami;

- przeciążenie kanalizacji;

- wypieranie powierzchni biologicznie czynnych;

- $\quad$ wypieranie naturalnych ekosystemów, zagrożenie dla bioróżnorodności.

Następstwem zjawisk opisywanych powyżej jest również stały wzrost zachorowań na choroby układu oddechowego a także choroby wynikające z tzw. stresu miejskiego.

\section{ROZWÓJ ZRÓWNOWAŻONY}

Ideę zrównoważonego rozwoju streszcza pierwsze zdanie raportu WCED (Światowa Komisja ds. Środowiska i Rozwoju) z 1987 r. „Na obecnym poziomie cywilizacyjnym możliwy jest rozwój zrównoważony, to jest taki rozwój, w którym potrzeby obecnego pokolenia mogą być zaspokojone bez umniejszania szans przyszłych pokoleń na ich zaspokojenie".

Warto przypomnieć, że pojęcie rozwoju zrównoważonego pochodzi pierwotnie z leśnictwa - oznaczało ono sposób gospodarowania lasem polegający na tym, że wycina się tylko tyle drzew, ile może w danym miejscu odrosnąć. Współczesna idea rozwoju zrównoważonego zakłada, że ludzkość w podobny sposób powinna traktować wszystkie zasoby środowiska naturalnego, w tym źródła energii oraz pożywienia.

Zgodnie z celami strategii „Europa 2020”, Unia Europejska dąży do osiągnięcia wzrostu gospodarczego, który będzie inteligentny - dzięki bardziej efektywnym inwestycjom w edukację, badania naukowe i innowacje oraz zrównoważony, co oznacza m.in. budowanie tzw. gospodarki niskoemisyjnej (korzystającej z zasobów w sposób racjonalny i oszczędny) i ochronę środowiska naturalnego, ze szczególnym naciskiem na ograniczenie emisji gazów cieplarnianych i zapobieganie utracie bioróżnorodności ${ }^{3}$. Zrównoważony rozwój gospodarczy ma opierać się również na innowacyjnych, przyjaznych dla środowiska technologiach i metodach produkcji a także efektywnych, inteligentnych sieciach energetycznych.

\footnotetext{
${ }^{3}$ 14.ec.europa.eu/europe2020/europe-2020-in-a-nutshell/priorities/sustainable-growth/index_pl.htm (dostęp: kwiecień 2016 r.)
} 
Unijne cele służące zapewnieniu zrównoważonego rozwoju obejmują m.in. ograniczenie emisji gazów cieplarnianych o $20 \%$ do 2020 r., w stosunku do poziomu z 1990 r., zwiększenie do $20 \%$ udziału energii ze źródeł odnawialnych w ogólnym zużyciu energii, a także dążenie do zwiększenia efektywności wykorzystania energii o 20\%. Celem UE jest również realizacja polityki przemysłowej, która wspiera przedsiębiorstwa - zwłaszcza małe firmy - w reagowaniu na zmiany, jakie niosą ze sobą globalne ocieplenie i zmiana klimatu i wynikająca $\mathrm{z}$ nich konieczność przejścia na gospodarkę niskoemisyjną ${ }^{4}$. Politykę taką można kształtować jedynie w oparciu o współpracę ze światem biznesu, środowiskami naukowymi, organizacjami pozarządowymi i przedstawicielami konsumentów.

Globalne zapotrzebowanie na zasoby naturalne stale rośnie, co z kolei zwiększa presję na środowisko. Obowiązkiem wynikającym ze stosowania się do zasad rozwoju zrównoważonego jest minimalizowanie wykorzystania tych zasobów, m.in. poprzez szerzenie innowacyjnych rozwiązań technologicznych.

Jedna $\mathrm{z}$ technologii najczęściej popieranych przez instytucje zaangażowane w walkę z następstwami zmian klimatu (m.in. przez C40 - Cities Climate Leadership Group), jest technologia dachów zielonych.

Technologia dachów zielonych, stosowana na obszarach silnie zurbanizowanych, przynosi bardzo wiele korzyści, zarówno dla środowiska naturalnego, jak i mieszkańców miast. Biorąc pod uwagę różnorodność jej pozytywnych aspektów, jest to technologia wzorcowa dla idei rozwoju zrównoważonego.

\section{ZIELONE DACHY A OCHRONA ŚRODOWISKA}

„Zielony dach” (ang. green roof, niem. Dachbegrünung) to nazwa jednej z technologii pokryć dachowych, składającej się z charakterystycznych elementów konstrukcyjnych, tworzących kilka warstw. Wierzchnia warstwa profilu dachu zielonego umożliwia wegetację roślin. Zwyczajowo, zielonym dachem nazywa się typ stropodachu, który oprócz swoich podstawowych funkcji, pełni również rolę powierzchni biologicznie czynnej. Technologia zielonego dachu może być stosowana pod powierzchnią terenu, na poziomie gruntu lub ponad nim, wg Prawa budowlanego, połowa powierzchni dachu zielonego (nie mniejsza jednak niż $10 \mathrm{~m}^{2}$ ), zaliczana jest do terenów biologicznie czynnych.

Zielone dachy mogą być instalowane zarówno na dachach obiektów nowych, jak $\mathrm{i}$ istniejących, po odpowiedniej adaptacji. Mogą być stosowane na powierzchniach bardzo dużych (np. dachach hipermarketów), jak i nieprzekraczających $1 \mathrm{~m}^{2}$. W zależności od rodzaju zielonego dachu, stosuje się roślinność niską (zielone dachy ekstensywne) lub typową dla ogrodów (zielone dachy intensywne) (fot. 1-2).

Zielone dachy ekstensywne, nazywane także dachami ekologicznymi, to technologia mająca na celu maksymalne wykorzystanie walorów ekologicznych zielonego dachu. System uprawy ekstensywnej w zamyśle obejmuje dachy nieużytkowe i ma pełnić funkcje wyłącznie związane z ochroną środowiska i poprawą wydajności energetycznej budynku. Dzięki stosowaniu małej ilości substratu i specyficznej roślinności, a także minimalnym nakładom na utrzymanie, cena dachów ekstensywnych jest stosunkowo niska. 80\% dachów zielonych, istniejących $w$ krajach Europy Zachodniej i USA, to dachy

\footnotetext{
${ }^{4}$ Ibidem.
} 
ekstensywne ${ }^{5}$. Stosowanie tej technologii w środowisku miejskim, zapewnia korzyści natury ekologicznej, ekonomicznej i społecznej.

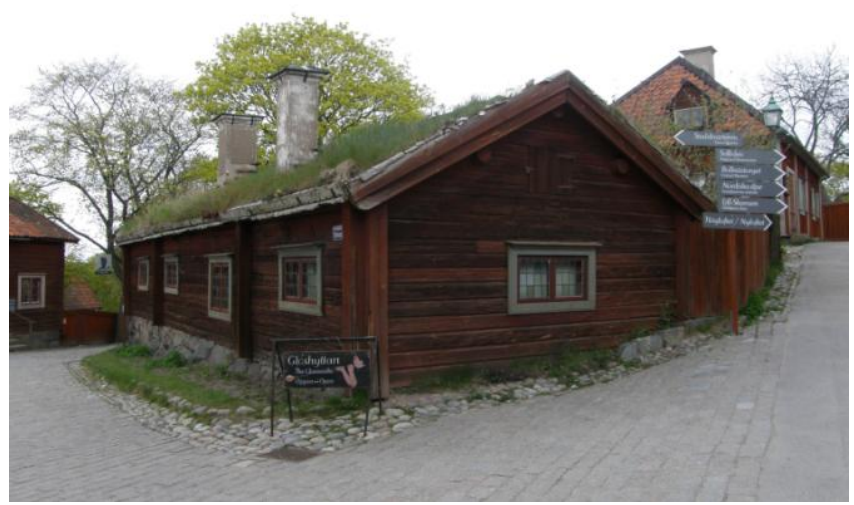

Fot. 1. Zielony dach na pochyłym dachu budynku historycznego

Źródło: fot. K. Kwiecińska.

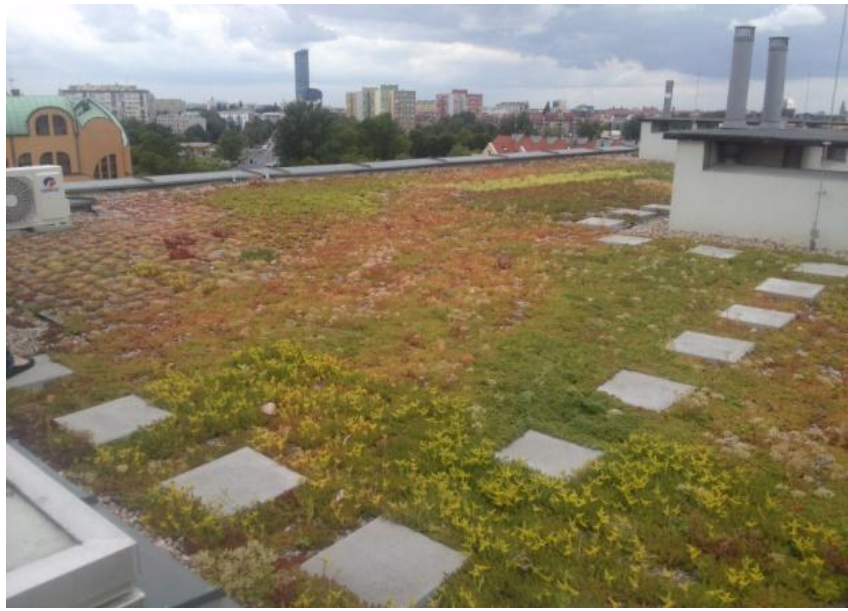

Fot. 2. Współczesny ekstensywny zielony dach na dachu płaskim

Źródło: fot. K. Kwiecińska.

- Pochłanianie zanieczyszczeń i gazów cieplarnianych z powietrza:

nadmierna emisja zanieczyszczeń powietrza i przekroczenia ich dopuszczalnych stężeń, odpowiadają za niską jakość powietrza w miastach. Do głównych zanieczyszczeń powietrza należą: dwutlenek siarki $\left(\mathrm{SO}_{2}\right)$, tlenki azotu $\left(\mathrm{NO}_{\mathrm{x}}\right)$, pyły (PM10, PM2.5, PM1),

5 P. Kożuchowski, E. Kożuchowska, Dach zielony - skuteczna metoda zabezpieczania pokryć hydroizolacyjnych, „Inżynier Budownictwa” nr 5/2009, 86-90. 
lotne związki organiczne (LZO), wielopierścieniowe węglowodory aromatyczne (WWA), tlenek węgla $(\mathrm{CO})$, dwutlenek węgla $\left(\mathrm{CO}_{2}\right)$, ozon troposferyczny $\left(\mathrm{O}_{3}\right)$, metale ciężkie. Zanieczyszczenie powietrza jest powodem m.in. licznych schorzeń u ludzi i zwierząt, wtórnego skażenia wody i gleby a także niszczenia infrastruktury miejskiej.

Zielone dachy, jak każda inna powierzchnia biologicznie czynna, przeprowadzają wymianę gazową. W procesie fotosyntezy, rośliny asymilują dwutlenek węgla, który jest związkiem niezbędnym dla życia roślin, natomiast produktem ubocznym reakcji fotosyntezy jest tlen - niezbędny dla życia ludzi i zwierząt. Zielone dachy przyczyniają się do redukcji emisji $\mathrm{CO}_{2}$ na trzy sposoby - poprzez naturalną sekwestrację dwutlenku węgla w biomasie roślin, poprzez zwiększanie efektywności energetycznej budynków na dachach których zainstalowany jest dach zielony oraz łagodzenie zjawiska miejskiej wyspy ciepła. Zielone dachy wykazują również zdolność do absorpcji niektórych zanieczyszczeń (m.in. niektórych LZO i WWA) z powietrza, w tym związków toksycznych dla człowieka i zwierząt. Przyczyniają się także do usuwania zanieczyszczeń pyłowych.

- Retencja wód opadowych:

zabudowę miejską charakteryzuje przewaga powierzchni nieprzepuszczalnych dla wody (np. asfalt, beton, pokrycia dachów), które zastępują naturalne, porośnięte roślinnością powierzchnie przepuszczalne. Ich brak w terenach zurbanizowanych powoduje bezpośredni spływ wód opadowych po powierzchniach uszczelnionych do systemu kanalizacyjnego, co przekłada się na duże obciążenia kanalizacji, jej częste awarie i kosztowną konserwację ${ }^{6}$. Przeciążenie kanalizacji skutkuje także zwiększeniem ryzyka wystąpienia powodzi oraz lokalnych podtopień, szczególnie w przypadku wystąpienia krótkich, gwałtownych ulew. Struktura zagospodarowania terenu ograniczająca retencję i infiltrację wody, ogranicza również możliwość przedostawania się wód opadowych do wód gruntowych, których zasoby już dziś w wielu miastach Polski nie są wystarczające na potrzeby zaopatrzenia ludności w wodę ${ }^{7}$. Wskazuje to na konieczność zwiększenia w miastach tzw. rozproszonej retencji wody opadowej, czyli ilości zrównoważonych systemów drenażu, których podstawowym zadaniem jest zatrzymanie części opadu poprzez retencję $\mathrm{i}$ infiltrację ${ }^{8}$.

Zielone dachy są jednym $\mathrm{z}$ najbardziej efektywnych rozwiązań pozwalających na redukcję odpływu powierzchniowego. Ilość opadu zatrzymywanego na zielonym dachu zależy od rodzaju profilu i typu zastosowanej roślinności, jednak nawet dachy o najniższej grubości warstwy zatrzymują od ok. $45 \%$ opadu rocznego w danym miejscu, spowalniając równocześnie odpływ pozostałej części deszczówki ${ }^{9}$.

Retencja wód opadowych pozwala uniknąć kosztów ich odprowadzania, zapewnia również ograniczenie i spowolnienie odpływu deszczówki do kanalizacji, co przeciwdziała jej okresowym przeciążeniom. Umożliwia to inwestycje budowlane na terenach pozbawionych sieci kanalizacyjnych lub na obszarach gdzie infrastruktura

\footnotetext{
${ }^{6}$ J. Lukaszkiewicz, Zielone dachy ekstensywne jako adaptacja powierzchni straconej $w$ osiedlach mieszkaniowych, „Dachy Płaskie” nr 4 (9) 2010.

${ }^{7}$ E. Burszta-Adamiak, A. Sylwester, Zielone dachy - alternatywne rozwiąanie dla problemów urbanizacji, „Inżynier Budownictwa” 08.2010, s. 64-67.

${ }^{8}$ M. Schmidt, Dachy zielone a energooszczędność, „Dachy Płaskie” nr 1 (6) 2011.

${ }^{9}$ J. Czemiel Berndtsson, Green roof performance towards management of runoff water quantity and quality: a review, "Ecological Engineering" 36 (2010) 351-360.
} 
kanalizacyjna jest niewystarczająca dla standardowej zabudowy. Poprzez stosowanie zielonych dachów, można również ograniczać lub eliminować opłaty za odprowadzanie do kanalizacji wody deszczowej ${ }^{10}$. Zielone dachy obniżają też temperaturę spływów, w porównaniu z wodami opadowymi odpływającymi z tradycyjnych pokryć dachowych w czasie gorących dni. Ma to pozytywny wpływ na kondycję odbiorników naturalnych, a także żyjące w nich organizmy ${ }^{11}$. Jednocześnie zielone dachy działają jak filtr zatrzymujący zanieczyszczenia niesione wraz ze spływami opadowymi, dzięki czemu nie trafiają one do odbiornika. Zanieczyszczenia pyłowe osadzają się na częściach nadziemnych roślin, a następnie wraz $\mathrm{z}$ opadem atmosferycznym zostają spłukane do podłoża ${ }^{12}$. Wody opadowe zatrzymywane $w$ profilu zielonego dachu są częściowo wykorzystywane przez rośliny w okresach bezdeszczowych, a znaczny ich procent odparowuje, zwiększając w ten sposób wilgotność powietrza. Woda w wyniku odparowywania przyczynia się do poprawy warunków klimatycznych i bilansu wodnego terenów zurbanizowanych.

- Ochrona mikroklimatu miejskiego i zwalczanie miejskiej wyspy ciepła:

struktura zagospodarowania terenów zurbanizowanych, charakteryzująca się brakiem powierzchni porośniętych roślinnością, skutkuje nie tylko zagrożeniami związanymi $\mathrm{z}$ brakiem możliwości retencjonowania wód pochodzących z odpływu powierzchniowego, lecz również ze zmianą zawartości pary wodnej w atmosferze, zaburzeniem wilgotności powietrza i mikroklimatu a także występowaniem zjawiska miejskiej wyspy ciepła.

W krajobrazie nieprzekształconym, czyli na obszarach pokrytych roślinnością, ok. $80 \%$ opadu atmosferycznego ulega wyparowaniu $\mathrm{w}$ procesie ewapotranspiracji ${ }^{13}$. W bilansie energetycznym terenów miejskich, nawet do $95 \%$ promieniowania słonecznego zamieniane jest na ciepło ${ }^{14}$. Ciepło akumulowane jest następnie przez asfalt, beton, powierzchnie dachowe czy elewacje budynków, które jako powierzchnie nieprzepuszczalne, nie mają możliwości oddania ciepła w procesie chłodzenia wyparnego, czyli chłodzenia poprzez wyparowanie cieczy. Temperatura powierzchniowa dachów $\mathrm{z}$ tradycyjnym, bitumicznym pokryciem, może sięgać nawet $100^{\circ} \mathrm{C}^{15}$. Zwiększone promieniowanie cieplne $\mathrm{z}$ powierzchni utwardzonych o niskim albedo (czyli silnie pochłaniających ciepło), powoduje, że temperatura wewnątrz budynków rośnie, co prowadzi do dyskomfortu termicznego i zwiększonych nakładów energetycznych na chłodzenie i klimatyzację ${ }^{16}$. Ciepło jest również oddawane $\mathrm{z}$ powrotem do atmosfery, przyczyniając się do lokalnego wzrostu temperatury. W ten sposób powstaje efekt tzw. miejskiej wyspy ciepła, rozumianej jako termiczne uprzywilejowanie miasta w stosunku do niezabudowanych obszarów otaczających. W skali roku, średnia różnica temperatur pomiędzy tymi obszarami może dochodzić nawet do $3^{\circ} \mathrm{C}$, a różnice dobowe mogą sięgać

\footnotetext{
${ }^{10}$ I. Kupryś-Lipińska, P. Kuna, I. Wagner, Woda w przestrzeni miejskiej a zdrowie mieszkańców, Zrównoważony Rozwój - Zastosowania, Woda w Mieście, s Kraków 2014, s. 49-57.

${ }^{11}$ E. Burszta-Adamiak, Mechanizmy finansowe gospodarowania wodami opadowymi w miastach, Zrównoważony Rozwój - Zastosowania, Woda w Mieście, Kraków 2014, s. 59-73.

${ }^{12}$ I. Kupryś-Lipińska, P. Kuna, I. Wagner, Woda w przestrzeni miejskiej s. 49-57.

${ }^{13}$ E. Burszta-Adamiak, A. Sylwester, Mechanizmy finansowe..., s. 64-67.

${ }^{14}$ Ibidem.

${ }^{15}$ Zasady projektowania i wykonywania zielonych dachów i żyjacych ścian. Poradnik dla gmin, Stowarzyszenie Gmin Polska Sieć „Energie Cities”, Kraków 2013.

${ }^{16}$ E. Burszta-Adamiak, A. Sylwester, Mechanizmy finansowe..., s. 64-67.
} 
$10^{\circ} \mathrm{C}^{17}$. W terenach zurbanizowanych mniejsza jest też prędkość wiatru, co utrudnia przewietrzanie miast i dopływ powietrza o niższej temperaturze, jak również sprzyja zapyleniu powietrza.

Zgodnie z Dyrektywą Parlamentu Europejskiego i Rady z dnia 16 grudnia 2002 r. w sprawie charakterystyki energetycznej budynków (2002/91/EC): „,[należy] dać priorytet strategiom poprawiającym charakterystyki energetyczne budynków (...). W tym celu powinien nastąpić dalszy rozwój pasywnych technologii chłodzenia, a przede wszystkim tych poprawiających warunki klimatyczne wnętrz oraz mikroklimat wokół budynków". Jedynym rozwiązaniem poprawiającym charakterystyki energetyczne budynków, warunki klimatyczne wnętrz oraz mikroklimat wokół budynków jednocześnie, jest technologia zielonego dachu. Zielone dachy umożliwiają zwiększenie wilgotności powietrza poprzez wprowadzenie do miast powierzchni porośniętych roślinnością, dzięki czemu przyczyniają się do poprawy bilansu wodnego terenów zurbanizowanych i poprawiają mikroklimat $\mathrm{w}$ bezpośrednim otoczeniu budynku. Ponadto chronią dach oraz wnętrze budynku przed przegrzewaniem się. Dzięki instalacji zielonego dachu następuje także redukcja emisji ciepła $\mathrm{z}$ nagrzanych budynków, co $\mathrm{w}$ przypadku stosowania tej technologii na szeroką skalę, najprawdopodobniej przyczyniłoby się do zauważalnej redukcji efektu miejskiej wyspy ciepła.

- Zwiększanie efektywności energetycznej budynków:

Sektor budowlany pochłania ponad $40 \%$ energii zużywanej w Unii Europejskiej ${ }^{18}$. Największymi źródłami zużycia energii w budynkach są systemy ogrzewania i klimatyzacji, zapotrzebowanie na ciepło generuje w Polsce aż 55\% kosztów utrzymania nieruchomości i odpowiada za zużycie ok. $75 \%$ energii dostarczanej do budynków ${ }^{19}$.

Proces wytwarzania energii, zarówno cieplnej, jak i elektrycznej, wymaga spalania paliw kopalnych, co wiąże się z emisją m.in. $\mathrm{CO}_{2}$. Sektor budowlany przyczynia się również do prawie 50\% emisji gazów cieplarnianych w Unii Europejskiej - tyle samo emitują przemysł i transport razem ${ }^{20}$.

Instalacja zielonego dachu jest najbardziej efektywnym ekonomicznie sposobem na zmniejszenie zużycia energii $\mathrm{w}$ budownictwie przy jednoczesnym osiągnięciu poprawy warunków klimatycznych wnętrz oraz mikroklimatu wokół budynków, powierzchnia biologicznie czynna, jaką jest zielony dach, przyczynia się również do pochłaniania $\mathrm{CO}_{2}$ i niektórych zanieczyszczeń z powietrza (pw.).

Technologia zielonych dachów jest rozwiązaniem powszechnym w budownictwie energooszczędnym i pasywnym. Z uwagi na możliwość zakładania zielonych dachów na budynkach istniejących, jest to również technologia wykorzystywana w procesach termomodernizacji budynków.

Izolacja termiczna, jaką zapewnia dach zielony, ma właściwości porównywalne z właściwościami izolacyjnymi wełny mineralnej. Dodatkowa ochrona termiczna dachu pozwala zredukować koszty ogrzewania oraz klimatyzacji poprzez zakup mniejszej ilości energii, a także poprzez instalowanie w budynkach mniejszej liczby urządzeń grzewczych i klimatyzatorów ${ }^{21}$.

\footnotetext{
${ }^{17}$ Ibidem.

${ }^{18}$ Zasady projektowania $i$ wykonywania zielonych dachów i żyjących ścian...

${ }^{19}$ Ibidem.

${ }^{20}$ Ibidem.

${ }^{21}$ Ibidem.
} 
Ponadto zielone dachy chronią dach przed nagrzewaniem się w najgorętsze dni w roku i w trakcie silnej operacji słonecznej (temperatura powierzchniowa dachów zielonych nie przekracza $30^{\circ} \mathrm{C}^{22}$ ), dzięki czemu obniża się temperatura wnętrz, szczególnie położonych w wyższych partiach budynku (w porównaniu do wnętrz w budynkach posiadających „tradycyjne” pokrycie dachowe). Instalacja zielonego dachu pozwala na obniżenie temperatury w pomieszczeniach pod nim średnio o $2-5^{\circ} \mathrm{C}^{23}$. Szacuje się, że zielone dachy pozwalają obniżyć wydatki na ogrzewanie i klimatyzację budynku nawet o 30\% w skali $\mathrm{roku}^{24}$.

- Wspieranie bioróżnorodności ekosystemów i rolnictwo miejskie:

proces poszerzania si miejskich terytoriów powoduje wypieranie naturalnych ekosystemów, w tym habitatów wielu gatunków flory i fauny. Miasta rozwijając się zajmują tereny wiejskie i leśne, często o charakterystycznej strukturze terenu, powodując degradację układu ekologicznego tych obszarów. Silne przekształcenie terenu, intensywna działalność człowieka i szczelna zabudowa to bezpośrednie przyczyny niskiej bioróżnorodności systemu przyrodniczego miast.

Zielone dachy, mimo że są powierzchniami zielonymi sztucznie wytworzonymi przez człowieka, maja udział w zwiększaniu bioróżnorodności terenów zurbanizowanych, poprzez zapewnienie warunków do życia roślinom a także wielu gatunkom zwierząt. Zielone dachy stanowią także potencjalne siedliska dla ptaków, które straciły swoje naturalne środowiska na skutek urbanizacji ${ }^{25}$. Niektóre gatunki zwierząt, zwłaszcza owady i ptaki, wykorzystują zielone dachy w poszukiwaniu pożywienia czy odpoczynku ${ }^{26}$.

Istnieją także dachowe ogrody botaniczne, specjalizujące się w utrzymywaniu rzadkich lub zagrożonych gatunków roślin i w celowym zwiększaniu bioróżnorodności terenów miejskich. Przykładami takich zielonych dachów są: Dachowy Ogród Botaniczny Augustenborg w Malmö, a także ogród botaniczny na dachu Biblioteki Uniwersytetu Warszawskiego.

W krajach wysoko rozwiniętych, na zielonych dachach praktykowane jest również rolnictwo miejskie, zjawisko cenne zarówno dla wspierania bioróżnorodności, jak i z punktu widzenia korzyści finansowych i społecznych. Pierwszą i największą na świecie farmą miejską na zielonym dachu jest Brooklyn Grange, w Nowym Jorku²7.

- Aspekty zdrowotne:

poza zagrożeniami dla zdrowia fizycznego, związanymi przede wszystkim z nadmiernym zanieczyszczeniem powietrza i zaburzeniem mikroklimatu, mieszkańcy miast narażeni są również na zagrożenia zdrowia psychicznego, związane ze zjawiskiem opisywanym jako stres miejski. Do głównych czynników stresotwórczych należą m.in. hałas oraz brak kontaktu z naturą. Szacuje się, że ponad 44\% populacji Unii Europejskiej, narażona jest na hałas przekraczający normy dopuszczalne wg $\mathrm{WHO}^{28}$.

\footnotetext{
${ }^{22}$ M. Schmidt, Dachy zielone a energooszczędnosść...

${ }^{23}$ Zasady projektowania $i$ wykonywania zielonych dachów $i$ żyjących ścian...

${ }^{24}$ P. Kożuchowski, E. Kożuchowska, Dach zielony - skuteczna metoda..., s. 86-90.

${ }^{25}$ N. Baumann, Ground-nesting birds on green roofs in Switzerland: preliminary observations, Urban Habitats ISSN 1541-7115, Dec, 2006.

${ }^{26}$ Ibidem.

${ }^{27}$ brooklyngrangefarm.com (dostęp: kwiecień 2016 r.).

${ }^{28}$ T.V. Renterghem, D. Bottledooren, Reducing the acoustical facade load from road traffic with green roofs, Building and Environment 44 (2009), p. 1081-1087.
} 
Zielone dachy minimalizują hałas - zarówno warstwa wegetacyjna, jak i pozostałe elementy profilu dachu, mogą absorbować lub odbijać określony zakres fal dźwiękowych. Badania wykazały, że już 12-centymetrowa warstwa substratu dachowego, redukuje dźwięk o ok. 40 decybeli (warstwa $20 \mathrm{~cm}$ redukuje go w zakresie $46-50 \mathrm{~dB})^{29}$.

Liczne badania dowodzą, że zieleń niweluje stres i zmniejsza poziom agresji. Wykazano, że instalowanie na biurowcach zielonych dachów, na których można spożywać posiłki i spędzać przerwy podczas pracy, podnosi wydajność i skuteczność pracowników $^{30}$. Możliwość wypoczynku w zieleni, a nawet sam jej widok z okna, przyspiesza proces zdrowienia i skraca okres pobytu chorych w szpitalach, dlatego w krajach wysoko rozwiniętych, powszechna jest adaptacja budynków szpitalnych do założenia zielonych dachów, m.in. z możliwością przebywania na nich pacjentów i ich rodzin ${ }^{31}$.

\section{PODSUMOWANIE I WNIOSKI}

Zielone dachy to przyrodniczo funkcjonujące elementy środowiska miejskiego. Technologia, którą można wprowadzać do miast bez kolizji z planami zagospodarowania przestrzennego, w procesach kompensacji przyrodniczej lub jako wartość dodaną do jakości środowiska.

Poza profitami ekonomicznymi wynikającymi z oszczędności energii, poprawy wydajności kanalizacji czy ochrony konstrukcji dachów, stosowanie dachów zielonych zapewnia również bezpośrednie korzyści finansowe dla inwestorów budynków, korzystających $\mathrm{z}$ tej technologii. Najważniejszymi jednak profitami, jakie z punktu widzenia idei rozwoju zrównoważonego, przynosi technologia dachów zielonych, są potencjalne oszczędności związane ze spadkiem zachorowalności na schorzenia wywołane negatywnym wpływem środowiska miejskiego, redukcją zjawiska miejskiej wyspy ciepła i ogólną poprawą jakości środowiska miejskiego, w przypadku stosowania tej technologii na szeroką skalę. Dachy zielone umożliwiają bardziej oszczędne wykorzystywanie zasobów środowiska naturalnego, w tym jednego z najważniejszych zasobów, jakimi są źródła energii.

Najlepszym dowodem na to, że jest to technologia spełniająca ideę rozwoju zrównoważonego, jest fakt że z uwagi na liczne korzyści, jakie zapewnia środowisku miejskiemu, została włączona w systemy ocen wielokryterialnych i certyfikacji dla budynków LEED i BREEAM. Certyfikaty te potwierdzają zastosowanie w procesie budowy oraz w okresie funkcjonowania obiektu rozwiązań o największym znaczeniu dla zrównoważonego rozwoju, umożliwiających m.in. oszczędność energii, racjonalne zużycie wody, minimalizację odpadów, wtórne wykorzystanie surowców czy wykorzystanie technologii gwarantujących redukcję emisji $\mathrm{CO}_{2}$.

W wielu krajach UE, a także w USA, Kanadzie czy Japonii, funkcjonuje ogromna liczba różnego rodzaju wymogów prawnych, a także form motywacyjnych, zachęcających do zakładania dachów zielonych, m.in. w postaci ulg podatkowych oraz subwencji dla deweloperów. Zachęty finansowe często obejmują również dopłaty do każdego $\mathrm{m}^{2}$ powierzchni zazielenionej $\mathrm{w}$ centrum miasta oraz bezzwrotne granty za każdy $\mathrm{m}^{2}$

\footnotetext{
${ }^{29}$ Zasady projektowania i wykonywania zielonych dachów i żyjących ścian...

${ }^{30}$ N. Baumann, Ground-nesting birds on green roofs in Switzerland: preliminary observations...

${ }^{31}$ earthtechling.com/2013/01/green-roofs-help-brighten-up-hospital-stays (dostęp: kwiecień 2016 r.).
} 
zielonego dachu wykonanego na prywatnym lub publicznym budynku ${ }^{32}$. We wrześniu 2015 r. wrocławscy radni przyjęli uchwałę dotyczącą zwolnień od podatku od nieruchomości właścicieli użytkowych lokali mieszkalnych posiadających dachy zielone, które będą zajmowały co najmniej połowę powierzchni dachu. Wysokość ulgi zależy od tego, ile kondygnacji ma budynek oraz od powierzchni dachu zielonego, zielony dach może również zostać założony na dachu budynku istniejącego ${ }^{33}$. Takie procedury wspierają inicjatywy oddolne mieszkańców miast, którzy kładą nacisk na konieczność zapewniania społeczności dostępu do rozwiązań proekologicznych.

Poprzez zwiększanie świadomości społecznej w tym zakresie i wspieranie partycypacji społecznej w projektach środowiskowych, stwarza się szansę na upowszechnienie idei rozwoju zrównoważonego i zmianę wizerunku dzisiejszych terenów miejskich.

\section{LITERATURA}

[1] Baumann N., Ground-nesting birds on green roofs in Switzerland: preliminary observations, Urban Habitats ISSN 1541-7115, Dec, 2006.

[2] brooklyngrangefarm.com (dostęp: kwiecień 2016 r.).

[3] Burszta-Adamiak E., Mechanizmy finansowe gospodarowania wodami opadowymi w miastach, Zrównoważony Rozwój - Zastosowania, Woda w Mieście, Fundacja Sendzimira, Kraków 2014, s. 59-73.

[4] Burszta-Adamiak E., Sylwester A., Zielone dachy - alternatywne rozwiazanie dla problemów urbanizacji, „Inżynier Budownictwa” 08.2010, s. 64-67.

[5] Czemiel Berndtsson J., Green roof performance towards management of runoff water quantity and quality: a review, "Ecological Engineering" 36 (2010), p. 351-360.

[6] Kożuchowski P., Kożuchowska E., Dach zielony - skuteczna metoda zabezpieczania pokryć hydroizolacyjnych, „Inżynier Budownictwa” nr 5/2009, 86-90.

[7] Kupryś-Lipińska I., Kuna P., I. Wagner, Woda w przestrzeni miejskiej a zdrowie mieszkańców, Zrównoważony Rozwój - Zastosowania, Woda w Mieście, Fundacja Sendzimira, Kraków 2014, s. 49-57.

[8] Łukaszkiewicz J., Zielone dachy ekstensywne jako adaptacja powierzchni straconej w osiedlach mieszkaniowych, „Dachy Płaskie” nr 4 (9) 2010.

[9] Renterghem T.V., Bottledooren D., Reducing the acoustical facade load from road traffic with green roofs, Building and Environment 44 (2009) 1081-1087.

[10] Schmidt M., Dachy zielone a energooszczędność, „Dachy Płaskie” nr 1 (6) 2011.

[11]Zasady projektowania $i$ wykonywania zielonych dachów $i$ żyjacych ścian. Poradnik dla gmin, Stowarzyszenie Gmin Polska Sieć „Energie Cities”, Kraków 2013.

[12] earthtechling.com/2013/01/green-roofs-help-brighten-up-hospital-stays (dostęp: kwiecień 2016 r.).

[13] wroclaw.pl/za-zielony-ogrod-na-dachu-nizszy-podatek (dostęp: kwiecień 2016 r.).

\footnotetext{
${ }^{32}$ E. Burszta-Adamiak, Mechanizmy finansowe...

${ }^{33}$ wroclaw.pl/za-zielony-ogrod-na-dachu-nizszy-podatek (dostęp: kwiecień 2016 r.).
} 
[14] 14.ec.europa.eu/europe2020/europe-2020-in-a-nutshell/priorities/sustainablegrowth/index_pl.htm (dostęp: kwiecień 2016 r.).

\section{GREEN ROOFS AS A MODEL TECHNOLOGY FOR SUSTAINABLE} DEVELOPMENT

The idea of sustainable development sets new priorities, corresponding with global economic, ecological and social concepts and provides an opportunity for the development of innovation. Sustainable development is based on activities focused on environmental protection and aims to meet the needs of present generations without compromising the ability of future generations to meet their own needs, in the face of ever growing population on the Earth. Sustainable development idea is one of the essential elements of development strategies proposed by the largest global organizations such as UN or the European Union. The priority of these strategies are innovative technological solutions, aimed to adapt human activities to changing environmental conditions. The extensive green roof technology used in urban areas brings numerous benefits both to the environment and urban residents. Taking into account the diversity of positive aspects of this technology, it is a model technology for the concept of sustainable development. By increasing social awareness on this matter, supporting the bottom-up initiatives and public participation in environmental projects, it is possible to give a chance to promote the idea of sustainable development and change the image of today's cities. It is also important to increase social awareness on climate and water resilience, i.a. by introducing green infrastructure into urban areas. Green infrastructure improves air quality, urban microclimate, helps to fight the urban heat island, provides distributed water retention, improves energy efficiency in buildings and contributes to biodiversity.

Keywords: sustainable development, green roofs, innovation, green infrastructure, climate change.

DOI:10.7862/rz.2017.hss.9

Przestano do redakcji: styczeń $2017 \mathrm{r}$.

Przyjęto do druku: marzec 2017 r. 
